\title{
Involvement of tumor necrosis factor receptor superfamily (TNFRSF) members in the pathogenesis of inflammatory diseases
}

\author{
Byungsuk Kwon ${ }^{1,3}$, Byung-Sam Kim ${ }^{1}$, \\ Hong Rae Cho', Jeong-Euy Park ${ }^{2}$ \\ and Byoung Se Kwon ${ }^{1}$ \\ ${ }^{1}$ The Immunomodulation Research Center \\ University of Ulsan, Ulsan $680-749$, Korea \\ ${ }^{2}$ Samsung Biomedical Research Institute and Cardiology Division \\ Samsung Medical Center, Sungkyunkwan University \\ School of Medicine, Seoul 135-710, Korea \\ ${ }^{3}$ Corresponding author: Tel, 82-52-259-2860; \\ Fax, 82-52-259-2740; E-mail, bkwon@mail.ulsan.ac.kr
}

Accepted 13 February 2003

Abbreviations: DC, dendritic cell; GITR, glucocorticoid-induced TNF receptor family-related gene; SLE, systemic lupus erythematosus

\section{Overview}

Current therapies for autoimmune diseases are not cures but merely palliatives, aimed at reducing symptoms. For the most part, these treatments provide nonspecific suppression of the immune system and thus do not distinguish between a pathogenic autoimmune response and a protective immune response. Recently emerging evidence not only has indicated the involvement of members of the TNF receptor/ligand superfamilies but also has revealed exciting innovative strategies for the treatment of autoimmune diseases and other chronic inflammatory diseases without depressing the immune response in general. In this review, we will discuss the regulatory mechanisms of TNF receptor/ligand family members, such as HVEM/ LIGHT, 4-1BB/4-1BBL, and GITR/GITRL that regulate $T$ and $B$ cell functions and participate in the process of inflammatory diseases. We will also discuss how intervening in the costimulatory pathways mediated by these molecules might have some potential as a therapeutic approach to immune disorders.

Keywords: autoimmune diseases; inflammation; receptors, tumor necrosis factor; tumor necrosis factor

\section{Introduction}

TNF receptor superfamily members have common motifs containing cysteine-rich pseudorepeats in the extracellular domain (Locksley et al., 2001). In contrast to the extracellular domain, the cytoplasmic domain does not share any distinctive motifs or even any significant sequence homology, except that of the death domain-containing members such as Fas, TNFR1, DR3, DR4, DR5, and DR6. At present, more than $20 \mathrm{TNF}$ receptor members have been identified. Members of the TNF receptor superfamily and their ligands are expressed mainly on immune cells. Their immunomodulatory functions have been well established in T-cell-mediated immune responses. These include enhancement of dendritic cell (DC) survival and priming capacity for $\mathrm{T}$ cells, optimal generation of effector T cells, optimal antibody responses, and amplification of inflammatory reactions.

The immune response is initiated by presentation of antigen-derived peptides in the complex of $\mathrm{MHC}$ by APCs to the T-cell receptor (TCR) of T cells. In this process, the axis of TNF receptor members and their ligands stimulate DCs and T cells in a mutual or unidirectional manner. Current evidence suggests that each member plays a distinct role in the generation of $\mathrm{CTL}, \mathrm{CD}^{+}$type 1 helper $\mathrm{T}$ (Th1), or Th2 subsets, even though in some cases, there is redundancy and synergy among members. TNF receptor family members and their ligands are also involved in the effector phase of immune responses to effectively exert their effector mechanism.

\section{4-1BB/4-1BBL in autoimmune diseases}

4-1BB is expressed on activated $\mathrm{CD}^{+} \mathrm{T}$ cells and $\mathrm{CD}^{+} \mathrm{T}$ cells. Recent studies have shown 4-1BB expression and its functions in a variety of cells (Kwon et al., 2000; Kwon et al., 2002). For example, $4-1 \mathrm{BB}$ is expressed on natural killer (NK) cells, NKT cells and $\mathrm{CD} 4^{+} \mathrm{CD} 25^{+}$regulatory $\mathrm{T}$ cells within the lymphoid cell lineage. Myeloid cells, including monocytes, neutrophils, DCs, and eosinophils, can also express 4-1BB. On the other hand, 4-1BB ligand (4-1BBL) expression is restricted on activated APCs, such as DCs, B cells, and macrophages. Importantly, the roles of $4-1 \mathrm{BB}$ have been revealed in these cells as well as in $T$ cells that have been the major target for 4-1BB studies (Heinisch et al., 2000; Heinisch et al., 2001; Futagawa et al., 2002; Gavin et al., 2002; 
MacHugh et al., 2002; Wilcox et al., 2002a, 2002b) Two important observations by Shuford et al. (1997) and Takahashi et al. (1999) greatly contributed to understanding of 4-1BB's role in immune responses. The former group demonstrated that $4-1 \mathrm{BB}$ signals preferentially induce proliferation of $\mathrm{CD}^{+} \mathrm{T}$ cells, and the latter group demonstrated that 4-1BB stimulation markedly increases superantigen-stimulated $\mathrm{CD8}^{+} \mathrm{T}$ cells in vivo. Two recent reports provided strong evidence that $4-1 \mathrm{BB}$ indeed regulates both clonal expansion and survival of $\mathrm{CD}^{+} \mathrm{T}$ cells, using elaborate experimental systems (Cooper et al., 2002; Maus et al., 2002). The molecular mechanism for promotion and prolongation of $\mathrm{CD}^{+} \mathrm{T}$ cell proliferation and survival by $4-1 \mathrm{BB}$ stimulation remains to be clarified but current evidence indicates that it is mediated, at least in part, through increased production of $\mathrm{IL}-2$ and expression of $\mathrm{Bcl}-\mathrm{X} \mathrm{L}$, an antiapoptotic BCL-2 family member (Lee et al., 2002; Maus et al., 2002). Studies using 4-1BBL-deficient or 4-1BB-deficient mice also clearly suggest a critical role for the 4-1BB costimulatory pathway in the expansion and differentiation of CTLs against viruses (DeBenedette et al., 1999; Tan et al., 1999; Kwon et al., 2002).

Considering the importance of $4-1 \mathrm{BB}$ in the regulation of $\mathrm{CD}^{+} \mathrm{T}$ cell response, the manipulation of the 4-1BB costimulatory pathway would be a conceivable immuntherapeutic approach. Indeed, it was shown that the systemic administration of agonistic anti-4-1BB monoclonal antibody was highly effective in eradicating large established tumors (Melero et al., 1997). In influenza virus lung infection, 4-1BB stimulation enhanced the primary $\mathrm{CD} 8^{+} \mathrm{T}$ cell responses by preferentially expanding $\mathrm{CD}^{+} \mathrm{T}$ cells that recognized nondominant epitopes, accompanied by great increase of cytotoxicity (Halstead et al., 2002). Interestingly, anti-4-1BB-mediated tumor elimination is a complex process that requires $\mathrm{CD}^{+} \mathrm{T}$ cells and NK cells as well as $\mathrm{CD}^{+} \mathrm{T}$ cells. In this case, it seems that augmentation of the tumor-specific cytotoxicity of $\mathrm{CD}^{+} \mathrm{T}$ cells is regulated by anti-4-1BB-stimulated NK cells via their proliferation and IFN- $\gamma$ secretion in response to anti-4-1BB monoclonal antibody (Wilcox et al., 2002b). An observation by Ye et al. (2002) has indicated the existence of another mechanism for tumor eradication by $4-1 \mathrm{BB}$ stimulation. They introduced a gene into mouse melanoma tumors that encodes a single-chain Fv (scFv) of anti-4-1BB monoclonal antibody. Using these transfected tumors that enhanced the strength of 4-1BB signaling better than anti-4-1BB monoclonal antibody itself, they demonstrated that both NK cells and $\mathrm{CD}^{+} \mathrm{T}$ cells but not $\mathrm{CD}^{+} \mathrm{T}$ cells were required for the anti-tumor effect for the scFv specific for 4-1BB. One suggested explanation for this observation is that NK cells are key effector cells to lyse tumors whose function can be enforced by IFN- $\gamma$ secreted by activated $\mathrm{CD}^{+} \mathrm{T}$ cells (Chen, 2002). In sum, two methods to improve costimulation via $4-1 \mathrm{BB}$ signals provide a promising strategy to cure poorly immunogenic tumors. One is to use tumor cells expressing cell-bound scFv fragments of anti-4-1BB monoclonal antibody as a therapeutic vaccine or to combine vaccination with tumor antigens with infusion of agonistic 4-1BB monoclonal antibody, which was shown to be effective in breaking immunological ignorance of poorly immunogenic tumors by Wilcox et al. (2002c). Another is to use 4-1BB stimulation to ex vivo expand tumor-specific CTLs for adoptive therapy. A promising system to achieve this goal has been developed by Carl June's group. They showed that artificial APCs, which were transfected by the 4-1BBL gene and were also engineered to be able to coat anti-CD3/CD28 monoclonal antibodies on their cell surface, enabled longterm expansion of bulk $\mathrm{CD}^{+}$cultures (Maus et al., 2002). Since recent clinical trials have validated the adoptive therapeutic capacity to treat melanoma patients (Dudley et al., 2002, Yee et al., 2002), the approach developed by Maus et al. might provide an invaluable tool to grow tumor-reactive $T$ cells ex vivo.

Less has been known about 4-1BB regulation of $\mathrm{CD}^{+} \mathrm{T}$ cells. However, there is accumulating evidence that $4-1 \mathrm{BB}$ is implicated in immune responses mediated by $\mathrm{CD}^{+} \mathrm{T}$ cells, including alloimmune responses (Blazar et al., 2001, Nozawa et al., 2001) and inflammation (Seko et al., 2001, Sun et al., 2002a). Although there is a controversy regarding the mechanism by which $4-1 \mathrm{BB}$ regulates $\mathrm{CD}^{+} \mathrm{T}$ cellmediated responses, as with $\mathrm{CD}^{+} \mathrm{T}$ cells, signaling through 4-1BB appears to promote cell proliferation and survival of $\mathrm{CD}^{+} \mathrm{T}$ cells in vitro (Gramaglia et al., 2000, Cannons et al., 2001, Wen, et al., 2002). Using 4-1BB transgenic mice that constitutively expressed 4-1BB on mature $T$ cells, we have recently demonstrated the involvement of $4-1 \mathrm{BB}$ in $\mathrm{CD} 4^{+} \mathrm{T}$ cell responses by regulating the clonal expansion and survival of $\mathrm{CD}^{+} \mathrm{T}$ cells in vivo (manuscript in submission).

A critical role of $4-1 \mathrm{BB}$ in the $\mathrm{CD} 4^{+} \mathrm{T}$ cell response suggests that intervening in the $4-1 \mathrm{BB}$ costimulatory pathway could provide an immunotherapeutic approach to the treatment of inflammatory diseases (Kwon et al., 2002). The first in vivo evidence that 4-1BB plays an important role in the inflammatory process has been provided by Seko et al. (2001). They have shown that in vivo administration of anti4-1BBL monoclonal antibody (thus blocking the 4$1 \mathrm{BB} / 4-1 \mathrm{BBL}$ interactions) significantly decreased the myocardial inflammation induced by coxackievirus B3. Similarly, our recent results have demonstrated that herpetic stromal keratitis (HSK) induced by herpes 
simplex virus type 1 (HSV-1) was completely prevented either by deleting 4-1BB (in 4-1BB-deficient mice) or by introducing anti-4-1BB monoclonal antibody (Seo et al., 2003). Puzzlingly, administration of agonistic anti-4-1BB monoclonal antibody resulted in the amelioration of experimental autoimmune encephalomyelitis (EAE), a mouse disease model corresponding to human multiple sclerosis (MS) (Sun et al., 2002a). The mechanism underlying the preventive effect of anti-4-1BB monoclonal antibody for $E A E$ described in this study seems to be that anti-4-1BB monoclonal antibody induces activation-induced cell death of antigen-specific $\mathrm{CD} 4^{+} \mathrm{T}$ cells, thereby inhibiting effector $T$ cell responses. Importantly, treatment with anti-4-1BB monoclonal antibody was effective in inhibiting the relapse of EAE. The same group of researchers has further proved the therapeutic effect of anti-4-1BB monoclonal antibody for inflammatory diseases by showing that anti-4-1BB monoclonal antibody blocks the disease progression of spontaneous systemic lupus erythematosus (SLE) (Sun et al., $2002 b$ ). This had been predictable, since anti-4-1BB monoclonal antibodies abrogate T-cell-dependent humoral immune responses (Mittler et al., 1999), and since SLE is a Th2-mediated autoimmune disease (i.e., autoantibodies are pathogenic).

It has been shown that anti-4-1BB monoclonal antibody can induce the suppression of antigen-specific humoral immune responses in primates (Hong et al., 2000). Thus, the possibility is high that humanized anti-4-1BB monoclonal antibody can be used to cure inflammatory diseases, especially Th2-mediated autoimmune diseases. Before a human clinical trial, it would be needed to understand the mechanisms how strong stimulation of the 4-1BB costimulatory pathway can make an abrogation of the production of antibodies that leads to curing autoimmune diseases. Emerging evidence suggests that the abrogation of antigen-specific humoral immune responses by agonistic anti-4-1BB monoclonal antibody may be due to depletion of antigen-specific $B$ cells (autoreactive $B$ cells in the case of SLE) in an IFN- $\gamma$-dependent manner (Sun et al., 2002b). According to the studies by Sun et al., treatment of Fas-deficient MRL/lpr mice (naturally prone to SLE) with anti-4-1BB monoclonal antibody induced drastic increase in apoptosis of double-negative $T$ cells and $B$ cells, accompanied by remarkable increase in granulocyte population in their spleens. Neutralization of these mice with anti- IFN- $\gamma$ monoclonal antibody reversed the effect of anti-4-1BB monoclonal antibody. In addition, IFN- $\gamma$-activated macrophages induced apoptosis of $\mathrm{B}$ cells. The proposed mechanisms for anti-4-1BB immunotherapy are diagrammed in Figure 1. In sum, even though it appears that 4-1BB may have several functions that depend on the activation status of the cell and subset

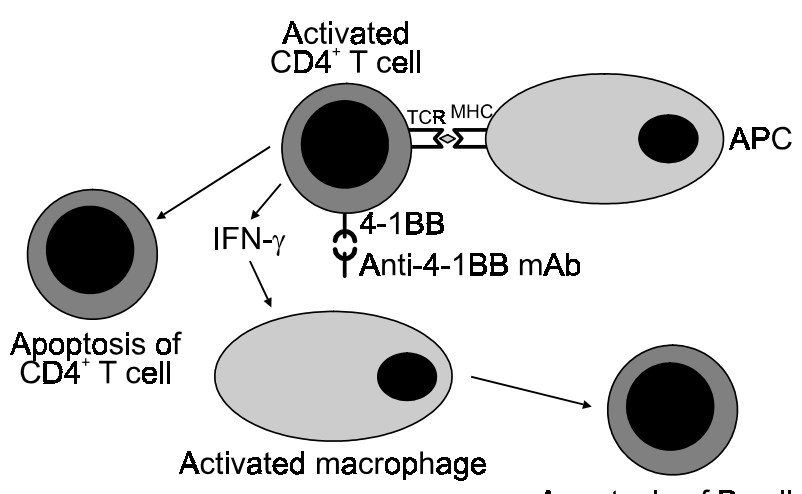

Apoptosis of B cell

Figure 1. Anti-4-1BB immunotherapy in Th2-mediated inflammatory diseases. If $4-1 \mathrm{BB}$ on $\mathrm{CD4}^{+} \mathrm{T}$ cells are stimulated by anti-4-1BB monoclonal antibody (mAb) during antigen presentation process, $\mathrm{CD4^{+ }}$ $T$ cells are activated and they secrete a large amount of IFN- $\gamma$. IFN- $\gamma$ strongly activates macrophages, which in turn can produce a death signal for $B$ cells. On the other hand, anti-4-1BB monoclonal antibody induces activation-induced cell death (AICD) of activated $\mathrm{CD} 4^{+} \mathrm{T}$ cells. As a result, the pathogenic antigen-specific $\mathrm{CD4}^{+} \mathrm{T}$ cells and $\mathrm{B}$ cells might be depleted from the body, resulting in curing of Th2-mediated inflammatory diseases.

of cell involved, it is believed that the type of immune response initiated is the most important factor to determine the outcome of 4-1BB stimulation by agonistic anti-4-1BB monoclonal antibody. In general, agonistic anti-4-1BB monoclonal antibody may turn out to be a valid therapeutic approach to treat Th2mediated autoimmune diseases such as SLE, rheumatoid arthritis, ulcerative colitis, whereas tools to block the 4-1BB costimulatory pathway such as anti4-1BBL monoclonal antibody may provide immunotherapy to treat Th1-mediated inflammatory diseases such as multiple sclerosis and Crohn's disease, and to prevent rejection of organ transplant (manuscript in submission). Agonistic anti-4-1BB monoclonal antibody may also be used as an immunotherapeutic agent to eradicate tumor or viral infection.

\section{HVEM/LIGHT in atherosclerosis and other inflammatory diseases}

Even though its etiology is complex, atherosclersosis is believed to be a chronic inflammatory disease (Ross, 1999). To date, many theories to account for the initiation of atherosclersosis have been proposed: namely, responses to injury, altered cholesterol metabolism, clonal proliferation of smooth muscle cells, autoimmunity against autoantigens which may or may not have a cross-reactivity with pathogen-derived antigens, or inflammation induced by infectious pathogens (Wick et al., 2001, Ludewig et al., 2002). Currently, there is a controversy regarding specific immune responses to antigens present in the vascular 
wall could initiate atherosclerotic processes. However, there is no doubt that the disease processes are manifested as inflammation involving interactions of a variety of molecules on immune cells. Thus, during the progression of atherosclerosis, immune cells such as $T$ cells and macrophages play a key role in maintaining/perpetuating immune-mediated vascular inflammation, on which process atherogenic risk factors such as altered cholesterol could exert an immunmodulatory effect locally.

Atherosclerosis is initiated by the accumulation of LDL in the subendothelial matrix (Luis, 2000). After modification, the LDL is able to stimulate the overlaying endothelial cells to produce proinflammatory molecules, including adhesion molecules, cytokines, and chemokines, which in turn mediate the entry of monocytes into the artery wall. During the initial inflammation, the recruited monocytes can be differentiated into macrophages and rapidly take up extensively modified LDL to form form cells, a major player of atherosclerosis. Puzzlingly, immunohistochemical studies demonstrate that from the beginning of atherosclersosis, fatty streak lesions contain a significant amount of activated $\mathrm{T}$ cells (especially $\mathrm{CD} 4^{+} \mathrm{T}$ cells) as well as macrophages (Waltner-Romen et al., 1998). $\mathrm{T}$ cells from atherosclerostic plaques are of polyclonal origin (Stemme et al., 1991) and can respond specifically to oxidized LDL (Stemme et al., 1995). These observations indicate that antigen-specific immune responses are involved in the initiation of atherosclerosis, and also suggest that $T$ cells may contribute to the initiation of atherosclerosis. However, it is possible that bystander $\mathrm{T}$ cells could be antigen-independently activated to secrete cytokines (Houtkamp et al., 2001). In general, inflammatory responses are orchestrated by Th1 cells. Activated Th1 cells secrete proinflammatory cytokines, which play a key role in recruiting and activating macrophages and neutrophils. In this regard, even though Th1 cells may not be sufficient to induce atherosclerosis, Th1 cells may be important component of the atherosclerotic process, together with other proatherogenic cells such as macrophages.

CD40, a member of the TNF receptor superfamily, plays a critical role in the process of atherosclerosis (Lutgens and Daemen, 2002). CD40 is expressed on $B$ cells and APCs such as DCs and macrophages and its ligand, CD40L (CD154), is expressed on activated $\mathrm{CD}^{+} \mathrm{T}$ cells (Noelle, 1996). Stimulation of DC CD40 by CD40L on activated $T$ cells results in DC activation in such a way that DCs secrete cytokines for T-cell differentiation and also induce upregulation of costimulatory molecules such as B7-1 and $B 7-2$, ligands for $C D 28$, an important costimulatory molecule for $\mathrm{T}$ cells. On the other hand, engagement of CD40 on $B$ cells by CD40L on activated CD4 ${ }^{+} T$ cells induces enhanced B-cell survival and plasma cell development with production of high affinity antibody. Further studies on the CD40-CD40L system revealed a broad spectrum of its roles beyond hematopoietic cells, as indicated by its expression on a variety of cells such as fibroblasts, endothelial cells, and smooth muscle cells (Mach et al., 1997). Recent studies have provided evidence that the CD40-CD40L system is key elements for initiating the arterial plaque formation (Mach et al., 1998) and for progressing established atherosclerotic lesions to more advanced unstable lesions (Lutgens et al., 1999; Schonbeck et al., 1999). Importantly, these studies have opened a promising possibility that disruption of the CD40 and CD40L system is a potential therapeutic tool for atherosclerosis.

Recently, our group has demonstrated that HVEM (TNFRSF14), another member of the TNF receptor superfamily, is implicated in atherosclerosis (Lee et al., 2001). HMEM was originally identified as one of many entry receptors for $\alpha$-herpesviruses (Montgomery et al., 1996). HVEM expression is most prominent in lymphoid tissues and cells, including $\mathrm{CD}^{+}$and $\mathrm{CD}^{+}$ $\mathrm{T}$ cells, CD19 ${ }^{+} \mathrm{B}$ cells, monocytes, DCs (Harrop et al., 1998, Morel et al., 2001), and neutrophils (our unpublished data), even though HVEM has a wide tissue distribution in the mRNA level (Kwon et al., 1997). The ligand for HVEM, LIGHT (TNFSF14), is expressed on activated $\mathrm{CD}^{+}$and $\mathrm{CD}^{+} \mathrm{T}$ cells, and immature DCs (Morel et al., 2000, Tamada et al., 2000a). HVEM stimulation by LIGHT leads to costimulation of $T$ cells (Tamada et al., 2000a) and DC activation (Morel et al., 2000). HVEM plays a role in immune responses such as tumor rejection (Tamada et al., 2000b), graft-versus-host disease (Tamada et al., 2000b; Tamada et al., 2002, Wilcox et al., 2002c), and autoimmune diseases (Shaikh et al., 2002; Wang et al., 2002).

We investigated the potential involvement of HVEM in atherosclerosis (Lee et al., 2001). First, our immunohistochemical analysis showed that HVEM colocalized with HLA-DR and CD69 in regions rich in foam cells of atherosclerotic plaques, indicating that HVEM is specifically expressed on foam cells. Even though we did not identify LIGHT-expressing cells in atherosclerotic plaques, Western blot analysis showed higher levels of LIGHT expression in atheromatous regions, compared with fibrous regions of the plaques. Indeed, HVEM expression is quickly upregulated by monocyte-activating stimuli such as TNF- $\alpha$ or LPS. Further, in vitro-differentiated macrophages expressed HVEM constitutively. Second, we demonstrated that using a monocytic cell line, THP-1, ligation of HVEM with an immobilized anti-HVEM monoclonal antibody induced the secretion of proatherogenic (proinflammtory) cytokines, TNF- $\alpha$ and IL-8, in the presence of IFN- $\gamma$. We further confirmed IL- 8 secretion by stimul- 
ation with LIGHT in THP-1. Third, we demonstrated the production of metalloproteases, MMP-1, MMP-9, and MMP-13 and their inhibitors, TIMP-1 and TIMP-2, in THP-1 by HVEM stimulation. We further found colocalization of HVEM with the metalloproteases but not with the two metalloprotease inhibitors in foam cell-rich regions of the atherosclerotic plaques. In sum, our data indicated that HVEM play a role in the progression of atherosclersosis.

Currently, we don't know the mechanism how the HVEM-LIGHT system mediate the atherosclerotic processes. Based on our observations, we want to propose several explanations for the HVEM action mechanism in atherosclerosis. First, HVEM may be involved in the amplification/perpetuation of chronic inflammation by inducing monocytes to secrete proinflammatory cytokines (i.e., TNF- $\alpha$ ) and chemokines. It is also possible that like CD40, HVEM expression is not restricted to foam cells in atherosclerotic lesions but could be found in smooth muscle cells and endothelial cells. Thus, signaling via HVEM may induce the production of proinflammatory cytokines and chemokines in a variety of cells during the processes of atherosclerosis. Second, metalloproteases produced by HVEM stimulation in macrophages may contribute to determining the stability of atherosclero-

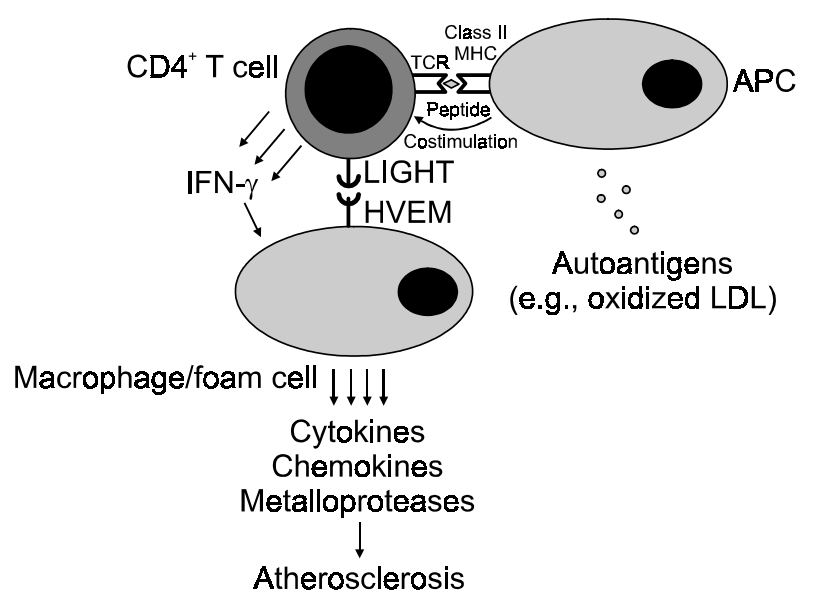

Figure 2. A schematic illustration for the potential contribution of the HVEM-LIGHT system to atherosclerosis. 1) Autoantigens (e.g., oxidized $(D L)$ may be captured and processed by professional antigenpresenting cells (APCs) such as DCs. 2) Processed peptides then may be presented to the T-cell receptor (TCR) of $\mathrm{CDA}^{+} \mathrm{T}$ cells in the context of MHC class II molecules by APCs. 3) Following TCR stimulation together with costimulation, $\mathrm{CD}^{+} \mathrm{T}$ cells will be activated, leading to expression of LIGHT and secretion of IFN- $\gamma$ in atherosclerotic lesions. 4) LIGHT on activated $\mathrm{CDA}^{+} \mathrm{T}$ cells then stimulates HVEM on macrophages in an IFN- $\gamma$-dependent manner, which will result in the induction of macrophages to produce proinflammatory cytokines, chemokines, and metalloproteases. 5) These inflammatory mediators and enzymes ultimately contribute to amplifying/perpetuating atherosclerotic processes. tic plaques. Other cytokines such as IL-8 secreted by HVEM stimulation may also be an important factor regulating the stability of atherosclerotic plaques in such a way that IL-8 downregulate metalloprotease inhibitors.

As with other members of the TNF and TNF receptor superfamilies, it is likely that the regulatory mechanism by which the HVEM-LIGHT system mediates the processes of atherosclerosis is complex. Biological activities mediated by HVEM are thought to be regulated by a complex network consisting of other TNF and TNF receptor family members: Natural ligands for HVEM are LIGHT and LT $\alpha$. LIGHT can also serve as a ligand for LT $\beta$ receptors (Mauri et al., 1998) and for a decoy receptor called DcR3 (TR6), which can also bind to FasL (Yu et al., 1999). Despite these known facts, a more feasible scenario as to the involvement of the HVEM-LIGHT system in atherosclerosis is that LIGHT on activated atherogenic CD4 ${ }^{+}$ $T$ cells may provide macrophages/foam cells with a strong inflammatory signal via HVEM during the development and progression of atherosclerotic lesions (Figure 2). This idea is supported by the studies by Wang et al. (2001). They have demonstrated that constitutive expression of LIGHT on T cells leads to severe inflammatory diseases in various peripheral tissues such as intestine, skin, and kidney. The autoimmune phenotypes in LIGHT transgenic mice is due to hyperactivation of $\mathrm{T}$ cells, since LIGHT transgenic mouse $T$ cells exhibit upregulation of activation markers, increased cytokine production, and expanded macrophage and granulocyte population, thereby resulting in splenomegaly and lymphoadenopathy. Currently it is not known whether the tissue destruction observed in the LIGHT transgenic mice is due to nonspecific inflammation by activated $T$ cells or true autoimmunity due to loss of central tolerance (Granger and Ware, 2001). Wang et al. have also provided evidence that the HVEM-LIGHT system is involved in the effector phase of immune responses. When HVEMFc fusion protein was treated into 5-to 6-week-old nondiabetic (NOD) mice, which spontaneously develop insulin-dependent diabetes mellitus (IDDM), the development of the disease was significantly prevented. Therefore, blockade of the HVEM costimulatory pathway may be of immunotherapeutic value in preventing acute GVHD or autoimmune diseases.

Since the involvement of the HVEM-LIGHT system in atherosclerosis has just begun to be revealed, further studies will be needed. In particular, meticulous expression analysis of HVEM/LIGHT and related molecules in atherosclerotic lesions, definition of HVEM/LIGHT in atherogenic T cells, and definition of the receptor/ligand pairs in appropriate animal model should provide novel insights into the significance of the HVEM-LIGHT system in atherosclersosis. 


\section{GITR/GITRL in inflammation}

GITR (glucocorticoid-induced TNF receptor family-related gene) was originally identified by comparing untreated and dexamethasone-treated murine $\mathrm{T}$ cell hybridoma cells (Nocentini et al., 1997). Later, human GITR and its ligand were identified by searching an EST (expressed sequence tag) database (Gurney et al., 1999; Kwon et al., 1999a, 1999b). The expression pattern of GITR is similar to that of 4-1BB in T cells. Like 4-1BB, GITR expression is upregulated on $T$ cells, and a high level of GITR is constitutively expressed on $\mathrm{CD}^{+} \mathrm{CD} 25^{+}$regulatory $\mathrm{T}$ cells (McHugh et al., 2002; Shimizu et al., 2002). Initial characterization of GITR functions revealed that the receptor could inhibit TCR-induced apoptosis in the T cell hybridoma cells that were used to clone the GITR gene (Nocentini et al., 1999). This was confirmed in a human $\mathrm{T}$ cell line (Gurney et al., 1999). In fact, $T$ cells of GITR-deficient mice exhibited a higher capacity to proliferate in response to TCR stimulation but underwent higher levels of activation-induced cell death (Ronchetti et al., 2002). Therefore, GITR plays an important role in the regulation of $T$ cell proliferation and TCR-mediated apoptosis. It remains to be clarified whether GITR delivers a negative signal for T-cell proliferation or not.

Over the past few years there has been an explosion in the number of publications focused on $\mathrm{CD} 4^{+} \mathrm{CD} 25^{+}$regulatory $\mathrm{T}$ cells (Figure 3 ). One field of regulatory $T$ cell studies is to find a marker for regulatory $T$ cells. A series of gene array analysis have identified surface molecules highly expressed in $\mathrm{CD} 4^{+} \mathrm{CD} 25^{+}$regulatory $\mathrm{T}$ cells in comparison with nonregulatory $\mathrm{CD}^{+}{ }^{+}$cells (McHugh et al., 2002). These include TNF receptor family members such as $4-1 \mathrm{BB}$,

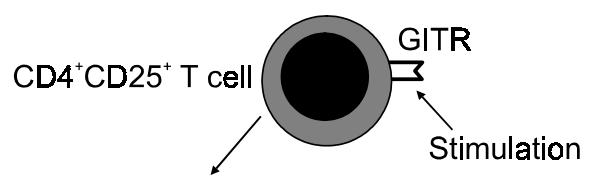

Loss of the suppressive activity

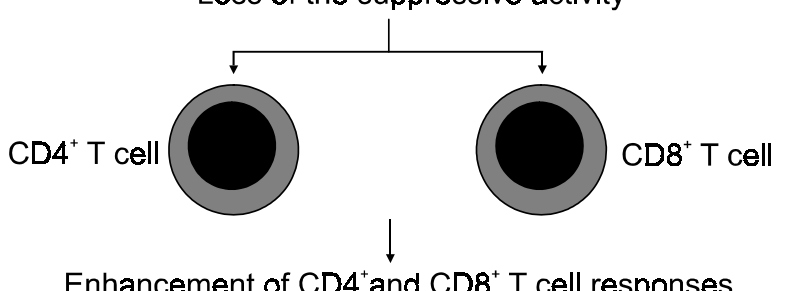

Enhancement of $\mathrm{CD}^{+}$and $\mathrm{CD} 8^{+} \mathrm{T}$ cell responses

Figure 3. A model for GITR action. GITR signals break the immunosuppressive activity of $\mathrm{CD} 4^{+} \mathrm{CD} 25^{+}$regulatory $\mathrm{T}$ cells for conventional $\mathrm{CD4}^{+}$and $\mathrm{CD}^{+} \mathrm{T}$ cells. As a consequence, $\mathrm{CD4}^{+}$and $\mathrm{CD} 8^{+} \mathrm{T}$ cell response might be enhanced.
OX40, and GITR. By using a different approach, Shimizu et al. (2002) also found that GITR was predominantly expressed on $\mathrm{CD}^{+} \mathrm{CD} 25^{+}$regulatory $\mathrm{T}$ cells. Despite its high levels of expression on $\mathrm{CD} 4^{+} \mathrm{CD} 25^{+}$ regulatory $T$ cells, like CD25 and CTLA4, there is a limitation of the use of GITR as a satisfactory marker for $\mathrm{CD}^{+} \mathrm{CD} 25^{+}$regulatory T cells, since GITR is upregulated in conventional $T$ cells upon activation. However, $\mathrm{CD} 4^{+} \mathrm{GITR}^{+} \mathrm{T}$ cells are equivalent to $\mathrm{CD} 4^{+} \mathrm{CD} 25^{+}$ regulatory $\mathrm{T}$ cells (Shimizu et al., 2002). In vitro studies showed that GITR signals abrogated the suppressive function of $\mathrm{CD}^{+} \mathrm{CD} 25^{+}$regulatory $\mathrm{T}$ cells (Shimizu et al., 2002, McHugh et al., 2002). Furthermore, in vivo administration of anti-GITR monoclonal antibody induced autoimmune gastritis (Shimizu et al., 2002). Therefore, it is clear that stimulation of GITR can break immunological self-tolerance. Since elucidation of the role of GITR in immune responses is in the nascent stage, there are many outstanding questions to be answered. First, it will be needed to be verified whether GITR stimulation can break the suppressive activity of regulatory $T$ cells in vivo. If this proves to be so, blockade of the GITR signaling pathway might be applied for treatment of inflammatory diseases. On the other hand, stimulation of the GITR signaling pathway might be used as a tool to enhance the anti-tumor activity of CTLs. Second, GITR may play a role in conventional T cells in that GITR functions as a costimulatory molecule in those cells (McHugh et al., 2002; Shimizu et al., 2002). Our unpublished results indicate that GITR stimulation increases $\mathrm{CD}^{+} \mathrm{T}$ cell responses but not $\mathrm{CD}^{+} \mathrm{T}$ cell responses. Moreover, it appears that the receptor differentially regulates the activity of Th1 and Th2 subsets of $\mathrm{CD}^{+} \mathrm{T}$ cells. Therefore, it will be interesting to define which branch of immune responses will be regulated by GITR. Finally, GITR may contribute to the development of $\mathrm{CD} 4^{+} \mathrm{CD} 25^{+}$regulatory $T$ cells. Even though GITR-deficient mice have the normal development of lymphoid organs and their cell populations (Ronchetii et al., 2002), it will be necessary to examine the population of $\mathrm{CD}^{+} \mathrm{CD} 25^{+}$regulatory $\mathrm{T}$ cells in more details.

\section{Concluding remarks}

The evidence is now overwhelming that TNF receptor members participate in the process of inflammatory diseases. This indicates intervening in TNF receptor signals as a therapy of choice for inflammatory diseases, including autoimmune diseases. However, to take full therapeutic advantage of manipulation of the costimulatory pathways mediated by TNF receptor family members, more has to be learned about action mechanisms of action of these molecules. 


\section{Acknowledgement}

This work was supported by grants from the SRC Fund to the IRC from the KOSEF and the Korean Ministry of Science and Technology.

\section{References}

Blazar BR, Kwon BS, Panoskaltsis-Mortari A, Kwak KB, Peschon JP, Talyor PA. Ligation of 4-1BB (CDw137) regulates graft-versus-host disease, graft-versus-leukemia, and graft rejection in allogeneic bone marrow transplant recipients. J Immunol 2001;166:3174-83

Cannons JL, Lau L, Ghumman B, DeBeneddette MA, Yagita $\mathrm{H}$, Okumura K, Watts TH. 4-1BB ligand induces cell division, sustains survival, and enhances effector function of CD4 and CD8 T cells with similar efficacy. J Immunol 2001;167: 1313-24

Chen L. Antibody gene therapy: Old wine in a new bottle. Nat Med 2002;8:333-4

Cooper D, Bansal-Pakala P, Croft M. 4-1BB (CD137) controls the clonal expansion and survival of CD8 T cells in vivo but does not contribute to the development of cytotoxicity. Eur J Immunol 2002;32:521-9

DeBenedette MA, Wen T, Bachmann MF, Ohashi PS, Barber $\mathrm{BH}$, Stockling KI, Peschon JJ, Watts TH. 4-1BB ligand (41BBL)-deficient mice and of mice lacking both 4-1BBL and CD28 reveals a role for 4-1BB in skin allograft rejection and in the cytotoxic $\mathrm{T}$ cell response to influenza virus. J Immunol 1999;163:4833-41

Dudley ME, Wunderlich JR, Robbins PF, Yang JC, Hwu P, Schwartzentruber DJ, Topalian SL, Sherry R, Restifo NP, Hubicki AM, Robinson MR, Raffeld M, Duray P, Seipp CA, Rogers-Freezer L, Morton KE, Mavroukakis SA, White DE, Rosenberg SA. Cancer regression and autoimmunity in patients after clonal repopulation with antitumor lymphocytes. Science 2002;298:850-4

Futagawa T, Akiba H, Kodama T, Takeda K, Hosoda Y, Yagita $\mathrm{H}$, Okumura K. Expression and function of 4-1BB and 4-1BB ligand on murine dendritic cells. Int Immunol 2002;14: $275-86$

Gavin MA, Clarke SR, Negrou E, Gallegos A, Rudensky A. Homeostasis and anergy of $\mathrm{CD} 4^{+} \mathrm{CD} 25^{+}$suppressor $\mathrm{T}$ cells in vivo. Nat Immunol 2002;3:33-41

Gramaglia I, Cooper D, Miner KT, Kwon BS, Croft M. Costimulation of antigen-specific CD4 T cells by 4-1BB ligand. Eur J Immunol 2000;30:392-402

Gurney AL, Marsters SA, Huang A, Pitti RM, Mark M, Baldwin DT, Gray AM, Dowd P, Brush J, Heldens S, Schow P, Goddard AD, Wood WI, Baker KP, Godowski PJ, Ashkenzai A. Idenfication of a new member of the tumor necrosis factor family and its receptor, a human ortholog of mouse GITR. Curr Biol 1999;9:215-8

Halstead ES, Mueller YM, Altman JD, Katsikis PD. In vivo stimulation of $\mathrm{CD} 137$ broadens primary antiviral $\mathrm{CD} 8^{+} \mathrm{T}$ cell responses. Nat Immunol 2002;3:536-41
Harrop JA, Reddy M, Dede K, Brigham-Burke M, Ly S, Tan KB, Silverman C, Eichman C, DiPrinzio R, Spampanato J, Porter T, Holmes S, Young PR, Truneh A. Antibodies to TR2 (herpesvirus entry mediator), a new member of the TNF receptor superfamily, block $\mathrm{T}$ cell proliferation, expression of activation markers, and production of cytokines. J Immunol 1998;161:1786-94

Granger SW, Ware CF. Turning on LIGHT. J Clin Invest 2001;108:1741-2

Heinisch IVWM, Daigle I, Knopfli B, Simon HU. CD137 activation abrogates granulocyte-macrophage colony-stimulating factor-mediated anti-apoptosis in neutrophils. Eur J Immunol 2000;30:3441-6

Heinisch IVWM, Bizer C, Volgger W, Simon HU. Functional CD137 receptors are expressed by eosinophils from patients with IgE-mediated allergic responses but not by eosinophils from patients with non-lgE-mediated eosinophilic disorders. J Allergy Clin Immunol 2001;108:21-28

Hong HJ, Lee JW, Park SS, Kang YJ, Chang SY, Kim KM, Kim JO, Jurthy KK, Payne JS, Yoon SK, Park MJ, Kim JC, Kang CY. A humanized anti-4-1BB monoclonal antibody suppresses antigen-induced humoral immune response in nonhuman primate. J Immunother 2000;23:613-21

Houtkamp MA, van der Wal AC, de Boer OJ, van der Loos CM, de Boer PAJ, Moorman AFM, Becker AE. Inerleukin-15 expression in atherosclerotic plaques: An alternative pathway for T-cell activation in atherosclerosis? Arterioscler Thromb Vasc Biol 2001;21:1208-13

Huang Q, Liu D, Majewski P, Schulte LC, Korn JM, Young RA, Lander ES, Hacohen N. The plasticity of dendritic cell responses to pathogens and their components. Science $2001 ; 294: 870-5$

Kwon B, Yu KY, Ni J, Yu GL, Jang IK, Kim YJ, Xing L, Liu D, Wang SX, Kwon BS. Identification of a novel activation-induced protein of the tumor necrosis factor receptor superfamily and its ligand. J Biol Chem 1999a;274:6056-61

Kwon B, Youn BS, Kwon BS. Functions of newly identified members of the tumor necrosis factor receptor/ligand superfamilies in lymphocytes. Curr Opin Immunol 1999b;10: $340-5$

Kwon B, Moon CH, Kang S, Seo SK, Kwon BS. 4-1BB: Still in the midst of darkness. Mol Cells 2000;10:119-26

Kwon B, Lee HW, Kwon BS. New insights into the role of 4-1BB in immune responses: Beyond $\mathrm{CD} 8^{+} \mathrm{T}$ cells. Trends Immunol 2002;23:378-80

Kwon BS, Hurtado JC, Lee ZH, Kwack KB, Seo SK, Choi $\mathrm{BK}$, Koller BH, Wolisi G, Broxmeyer HE, Vinay DS. Immune responses in 4-1BB (CD137)-deficient mice. J Immunol 2002; 168:5483-90

Kwon BS, Tan KB, Ni J, Oh KO, Lee ZH, Kim KK, Kim MH, Gentz R, Laing G, Harrop JA, Lyn SD, Silverman C, Porter TG, Truneh A, Young PR. A newly identified member of the TNF superfamily with a wide tissue distribution and involvement in lymphocyte activation. J Biol Chem 1997; 272:14272-6

Lee HW, Park SJ, Choi BK, Kim HH, Nam KO, Kwon BS. 4-1BB promotes the survival of $\mathrm{CD}^{+} \mathrm{T}$ lymphocytes by 
increasing expression of Bcl- $\mathrm{x}_{\mathrm{L}}$ and Bfl-1. J Immunol 2002; 169:4822-8

Lee WH, Kim SH, Lee BB, Kwon B, Song H, Kwon BS, Park JE. TNFRSF14 is involved in atherogenesis by inducing pro-inflammatory cytokines and matrix metalloproteinases. Arterioscler Thromb Vasc Biol 2001;21:2004-10

Locksley RM, Killeen N, Lenardo M. The TNF and TNF receptor superfamilies: Integrating mammalian biology. Cell 2001;104:487-501

Ludewig B, Zinkernagel RM, Hengartner H. Arterial inflammation and atherosclerosis. Trends Cardiovasc Med 2002; $12: 154-9$

\section{Luis AJ. Atherosclerosis. Nature 2000;407:233-41}

Lutgens E, Gorelik L, Daemen MJAP, de Muinck ED, Grewal IS, Koteliansky VE, Flavell RA. Requirement for CD154 in the progression of atherosclerosis. Nat Med 1999;5:1313-26

Lutgens E, Cleutjens KBJ, Heeneman S, Koteliansky VE, Burkly LC, Daemen MJAP. Both early and delayed antiCD40L antibody treatment induces a stable plaque phenotype. Proc Natl Acad Sci USA 2000;97:7464-9

Lutgens E, Daemen MJAP. CD40-CD40L interactions in atherosclerosis. Trends Cardiovasc Med 2002;12:27-32

Mach F, Schonbeck U, Sukhova GK, Bourcier T, Bonnefoy JY, Pober JS, Lobby P. Functional CD40 ligand is expressed on human vascular endothelial cells, smooth muscle cells, and macrophages: Implications for CD40-CD40 ligand signaling in atherosclerosis. Proc Natl Acad Sci USA 1997;94: 1931-6

Mach F, Schonbeck U, Sukhova GK, Atkinson E, Libby P. Reduction of atherosclerosis in mice by inhibition of CD40 signalling. Nature 1998;394:200-3

Mauri DN, Ebner R, Montgomery RI, Kochel KD, Cheung TC, Yu GL, Ruben S, Murphy M, Eisenberg RJ, Cohen GH, Spear PG, Ware CF. LIGHT, a new member of the TNF superfamily, and lymphotoxin are ligands for herpesvirus entry mediator. Immunity 1998;8:21-30

Maus MV, Thomas AK, Leonard DGB, Allman D, Addya K, Schlienger $\mathrm{K}$, Riley $\mathrm{JL}$, June $\mathrm{CH}$. Ex vivo expansion of polyclonal and antigen-specific cytotoxic $T$ lymphocytes by artificial APCs expressing ligands for the T-cell receptor, CD28 and 4-1BB. Nat Biotechnol 2002;20:143-8

McHugh RS, Whitters MJ, Piccirillo CA, Young DA, Shevach $\mathrm{EM}$, Collins $\mathrm{M}$, Byrne MC. $\mathrm{CD} 4^{+} \mathrm{CD} 25^{+}$immunoregulatory $\mathrm{T}$ cells: Gene expression analysis reveals a functional role for the glucocorticoid TNF receptor. Immunity 2002;16:311-23

Melero I, Shuford WW, Newby SA, Aruffo A, Ledbetter JA, Hellstrom KE, Mittler RS, Chen L. Monoclonal antibodies against the 4-1BB T-cell activation molecules eradicate established tumors. Nat Med 1999;3:682-5

Mittler RS, Bailey TS, Klussman K, Trailsmith MD, Hoffman MK. Anti-4-1BB monoclonal antibodies abrogate $T$ cell-dependent humoral immune responses in vivo through the induction of helper T cell anergy. J Exp Med 1999;190: $1535-40$

Montgomery RI, Warner MS, Lum BJ, Spear PG. Herpes simplex virus- 1 entry into cells mediated by a novel member of the TNF/NGF receptor family. Cell 1996;87:427-36

Morel Y, Schiano de Colella JM, Harrop J, Deen KC, Holmes SD, Wattam TA, Khandekar SS, Truneh A, Sweet RW, Gastaut JA, Olive D, Costello RT. Reciprocal expression of the TNF family receptor herpes virus entry mediator and its ligand LIGHT on activated T cells: LIGHT down-regulates its own receptor. J Immunol 2000;165:4397-404

Morel Y, Truneh A, Sweet RW, Olive D, Costello RT. The TNF superfamily members LIGHT and CD154 (CD40 ligand) costimulate induction of dendritic cell maturation and elicit specific CTL activity. J Immunol 2001;167:2497-86

Nocentini G, Giunchi L, Ronchetti S, Krausz LT, Bartoli A, Moraca R, Migliorati G, Riccardi C. A new member of the tumor necrosis factor/nerve growth factor receptor family inhibits T cell receptor-induced apoptosis. Proc Natl Acad Sci USA 1997;94:6216-21

Noelle R. CD40 and its ligand in host defense. Immunity $1996 ; 4: 415-9$

Nozawa K, Ohata J, Sakurai J, Hashimoto H, Miyajima H, Yagita $\mathrm{H}$, Okumur K, Azuma M. Preferential blockade of $\mathrm{CD8}^{+} \mathrm{T}$ cell responses by administration of anti-CD137 ligand monoclonal antibody results in differential effect on development of murine acute and chronic graft-versus-host diseases. J Immunol 2001;167:4981-6

Ronchetti S, Nocentini G, Riccardi C, Pandolfi P. Role of GITR in activation response of T lymphocytes. Blood 2002; 100:350-2

Ross R. Atherosclerosis An inflammatory disease. N Engl J Med 1999;240:115-26

Schonbeck U, Sukohova GK, Shimizu K, Mach F, Libby P. Inhibition of CD40 signaling limits evolution of established atherosclerosis in mice. Proc Natl Acad Sci USA 2000; 97:7458-63

Seo SK, Park HY, Cho JH, Kim WY, Jung HW, Kwon B, Kwon BS. Blocking 4-1BB/4-1BBL prevents herpetic stromal keratitis. J Immunol (In press)

Seko $Y$, Takahashi N, Oshima $H$, Shimozato O, Akiba $H$, Takeda K, Kobata T, Yagita H, Okumura K, Azuma M, Naga $R$. Expression of tumor necrosis factor (TNF) ligand superfamily co-stimulatory molecules CD30L, CD27L, OX40L, and 4-1BBL in murine hearts with acute myocarditis caused by coxakievirus B3. J Pathol 2001;195:593-603

Shaikh RB, Santee S, Granger SW, Butrovich K, Cheung $\mathrm{T}$, Kronenberg M, Cheroutre $\mathrm{H}$, Ware CF. Constitutive expression of LIGHT on T cells leads to lymphocyte activation, inflammation, and tissue destruction. J Immunol 2000;167: 6330-7

Shimizu J, Yamazaki S, Takahashi T, Ishida Y, Sakaguchi S. Stimulation of $\mathrm{CD} 25^{+} \mathrm{CD} 4^{+}$regulatory T cells through GITR breaks immunological self-tolerance. Nat Immunol 2002;3: $135-42$

Shuford WW, Klussman K, Tritchler DD, Loo DT, Chalupny J, Liadak AW, Brown TJ, Emswiler J, Raecho H, Larsen CP, Pearson TC, Ledbetter AL, Aruffo A, Mittler RS. 4-1BB costimulatory signals preferentially induce $\mathrm{CD}^{+} \mathrm{T}$ cell proliferation and lead to the amplification in vivo of cytotoxic T cell responses. J Exp Med 1997;186:47-55 
Stemme S, Rymo L, Hansson GK. Polyclonal origin of $T$ lymphocytes in human atherosclerotic plaques. Lab Invest $1991 ; 65: 654-60$

Stemme S, Faver B, Holm J, Wiklund O, Witztum JL, Hansson GK. T lymphocytes from human atherosclerotic plaques recognize oxidized low density liporprotein. Proc Natl Acad Sci USA 1995;92:3893-97

Sun $Y$, Lin $X$, Chen $H$, Wu $Q$, Subudhi SK, Chen L, Fu YX. Administration of agonistic anti-4-1BB monoclonal antibody leads to the amelioration of experimental autoimmune encephalomyelitis. J Immunol 2002a;168:1457-65

Sun $Y$, Lin X, Chen LM, Subudhi SK, Chen J, Koda R, Chen $\mathrm{L}, \mathrm{Fu}$ YX. Costimulatory molecule-targeted antibody therapy of a spontaneous autoimmune disease. Nat Med 2002b; 8:1405-13

Takahashi C, Mittler RS, Vella AT. Cutting Edge: 4-1BB is a bona fide CD8 T cell survival signal. J Immunol 1999; 162:5037-40

Tamada K, Shimozaki K, Chapoval Al, Zhai Y, Su J, Chen SF, Hsieh SL, Nagata S, Ni J, Chen L. LIGHT, a TNF-like molecule, costimulates $T$ cell proliferation and is required for dendritic cell-mediated allogeneic $\mathrm{T}$ cell response. J Immunol 2000a; 164:4101-10

Tamada K, Shimozaki K, Chapoval Al, Zhu G, Cica G, Flies $D$, Boone $T$, Hsu H, Fu YX, Nagata S, Ni J, Chen L. Modulation of T-cell-mediated immunity in tumor and graft-versus-host disease models through the LIGHT costimulatory pathway. Nat Med 2000b;6:283-8

Tamada K, Tamura H, Flies D, Fu YX, Celis E, Pease LR, Blazar BR, Chen L. Modulation of T-cell-mediated immunity in tumor and graft-versus-host disease models through the LIGHT co-stimulatory pathway. J Clin Invest 2002;109:54957.

Tan JT, Whitmire JK, Ahmed R, Pearson TC Larsen CP. 4-1BB ligand, a member of the TNF family, is important for the generation of antiviral CD8 $\mathrm{T}$ cell responses. $\mathrm{J}$ Immunol 1999;163:4859-68

Waltner-Romen M, Falkensammer G, Rabl W, Wick G. A previously unrecognized site of local accumulation of mono- nuclear cells: the vascular-associated lymphoid tissue. J Histochem Cytochem 1998;46:1347-50

Wang J, Lo JC, Foster A, Yu P, Chen HM, Wang Y, Tamada $\mathrm{K}$, Chen $\mathrm{L}$, Fu $\mathrm{YX}$. The regulation of $\mathrm{T}$ cell homeostasis and autoimmunity by T cell-derived LIGHT. J Clin Invest 2001; 108:1771-80

Wen T, Bukczynski J, Watts TH. 4-1BB ligand-mediated costimulation of human $T$ cells induces CD4 and CD8 $T$ cell expansion, cytokine production, and the development of cytolytic effector function. J Immunol 2002;168:4897-906

Wick $G$, Perschinka $H$, Millonig $G$. Atherosclerosis as an autoimmune disease: An update. Trends Immunol 2001;22: $665-9$

Wilcox RA, Chapoval Al, Gorski KS, Otsuji M, Shin T, Flies DB, Tamada K, Mittler RS, Tsuchiya H, Pardoll DM, Chen L. Cutting Edge: Expression of functional CD137 receptor by dendritic cells. J Immunol 2002a;168:4262-7

Wilcox RA, Tamada K, Strome SE, Chen L. Signaling through NK cell-associated CD137 promotes both helper function for $\mathrm{CD}^{+}$cytolytic $\mathrm{T}$ cells and responsiveness to IL-2 but not cytolytic activity. J Immumol 2002b;169:4230-6

Wilcox RA, Flies DB, Zhu G, Johnson AJ, Tamada K, Chapoval Al, Strome SE, Pease LR, Chen L. Provision of antigen and CD137 signaling breaks immunological ignorance, promoting regression of poorly immunogenic tumors. J Clin Invest 2002c;109:651-9

Ye Z, Hellstrom I, Hayden-Ledbetter M, Dahlin A, Ledbetter JA, Hellstrom KE. Gene therapy for cancer using single-chain Fv fragments specific for 4-1BB. Nat Med 2002;8:343-8

Yee C, Thompson JA, Byrd D, Reddell SR, Roche P, Celis $E$, Greenberg PD. Adoptive T cell therapy using antigenspecific $\mathrm{CD}^{+} \mathrm{T}$ cell clones for the treatment of patients with metastatic melanoma: In vivo persistence, migration, and antitumor effect of transferred T cell. Proc Natl Acad Sci USA 2002;99:16168-73

Yu KY, Kwon B, Ni J, Zhai Y, Ebner R, Kwon B. A newly identified member of tumor necrosis factor receptor superfamily (TR6) suppresses LIGHT-mediated apoptosis. J Biol Chem 1999;274:13733-6 